\title{
A Bibliometric Overview of University-Business Collaboration between 1980 and 2016
}

\author{
Claudia Olvera ${ }^{1}$, Jasmina Berbegal-Mirabent ${ }^{1,2}$, José M. Merigó ${ }^{3}$ \\ 1 Universitat Politècnica de Catalunya, Barcelona TECH, \\ Spain \\ 2 Universitat Internacional de Catalunya, \\ Spain \\ ${ }^{3}$ Universidad de Chile, \\ Chile
}

claudia.olvera@upc.edu, jberbegal@uic.es, jmerigo@fen.uchile.cl

\begin{abstract}
Bibliometrics is a research field that analyses bibliographic material from a quantitative point of view. Aiming at providing a comprehensive overview, this study scrutinises the academic literature in university business collaboration and technology transfer research for the period post the Bayh-Dole Act (1980-2016). The study employs the Web of Science as the main database from where information is collected. Bibliometric indicators such as number of publications, citations, productivity, and the $\mathrm{H}$-index are used to analyse the results. The main findings are displayed in the form of tables and are further discussed. The focus is on the identification of the most relevant journals in this area, the most cited papers, most prolific authors, leading institutions, and countries. The results show that the USA, England, Spain, Italy, and the Netherlands are highly active in this area. Scientific production tends to fall within the research areas of business and economics, engineering or public administration, and is mainly published in journals such as Research Policy, Technovation and Journal of Technology Transfer.
\end{abstract}

Keywords. University-industry collaborations, science to business, industry-science, technology transfer, bibliometrics.

\section{Introduction}

Knowledge is widely acknowledged to be one of the main engines for economic and social development of a country [33, 35]. Universities and research centres, either public or private, play a key role in both generating and disseminating this knowledge [28, 54]. Through the research mission, they generate cutting edge discoveries, expanding the boundaries of science, while the "third mission" implies the dissemination and exploitation of this knowledge, contributing to social growth and economic development [3, 22, 58]. Moreover, knowledge spillovers stimulate other research institutions to commercialize their research findings resulting in acceleration of economic growth. The establishment of university-business collaborations (UBC) is therefore central to this process in order to facilitate this knowledge flow from academia to industry [21].

Reasons for engaging in UBC have been widely documented in the literature. From the standpoint of universities, an important body of the literature has examined the function of the university and their departmental characteristics [52], as well as the technology transfer infrastructures that boost the commercialization of research results $[44,61]$. Other studies have shown that scientific productivity of a researcher is positively related to academic engagement in the industrial domain [8, $31,32]$. Going a step further, several works also found a positive connection between the quality of the research conducted and the probability of researchers participating in commercialisation activities [25, 51, 62]. 
From the industrial side, knowledge sharing between science and industry is a preliminary step for innovation [37]. In order to leverage markets and remain competitive, companies need to be continually alert of new developments. In this respect, universities offer firms a wide access to a variety of experts in various disciplines as well as appropriate infrastructure and state-of-the-art technologies, which can shorten the life cycle for industrial products [57, 66, 68]. Partnering with universities not only provides firms with an adequate cost-benefits extension of the R\&D resources (cutting-edge knowledge, equipment, facilities), but also helps firms to take advantage of emerging potential business opportunities, and evaluate the quality of the research into the company and update internal capabilities and skills [30]. Partnering with university scientists is also beneficial for companies, as this form of alliance gives legitimacy to research results [36].

Furthermore, universities can also conduct new research in specific fields that are of interest for firms [15]. Aiming at narrowing the gap between science and industry, many universities have created specific units and designed explicit programs to assist in this endeavour. Technology Transfer Offices (TTOs) and science parks are two clear examples. Acting as knowledge brokers, they are a bridge between academics, companies and venture capitalists, and their main objective is to facilitate the process of knowledge and technology transfer between the university and the company while infusing an entrepreneurial culture of research [17].

Nevertheless, despite the great support given to UBC, there are still significant impediments limiting their potential. Barriers mainly relate to the motivation incentives that drive academics and firms to engage in such a partnership. Science and industry operate differently. Their daily activities are highly tied to a specific organizational culture, mission and organizational practices [59]. Accordingly, goals might signal opposite directions. First, companies cannot evaluate the quality of the invention a priori, and researchers may have difficulties in evaluating the commercial profitability of their inventions [45]. Second, poor communication channels and low interest in academic research are other reasons that prevent universities and business from cooperating [6].
Universities have strong incentives for conducting basic research that leasing to new knowledge. On the other hand, industries seek solutions that make their operations and processes more competitive, their products more attractive, and consequently enable them to become more profitable $[1,55]$. Third, time-span is another critical factor. University research projects tend to require long periods of time, while industry demands short cycles in order to compete in the market and obtain competitive advantage [16, 26, 12].

Literature on UBC is abundant. The different stakeholders involved in this process (i.e., the universities, firms, and individual researcher) might explain this large corpus of both theoretical and empirical studies, as different approaches, and different points of view have been explored [22].

Another explanation for this diversity relies on the variety of forms in which UBC materialize, ranging from casual interactions in events such as meetings, conferences, recruitment of university graduates, or staff mobility, to more sophisticated agreements such as collaborative joint research, contract research, consulting, consortia, alliances, trade associations, interlocking directorates, equipment or other facilities [22,7].

Although this list is quite exhaustive, scholars converge on the difficulties of categorizing all potential mechanisms for UBC to take place [10]. All these mechanisms had been classified into six categories: (1) personal casual relationships, (2) personal relationships, (3) third party, (4) formal targeted agreements, (5) formal non-targeted agreements and (6) creation of focused structures [13]. Similarly, had been distinguished seven tools through which to strengthen UBC: (1) joint curriculum design and delivery, (2) lifelong learning, (3) student mobility, (4) professional mobility, (5) joint R\&D, (6) commercialization of joint R\&D, and (7) entrepreneurship [23]. Whatever the mechanism used, the formalization agreement is a very important step, as it monitors and regulates the relationship, avoiding conflict and mistrust between the parties [56].

Today, research in UBC enjoys good health and can be considered a recognised scientific field, with a myriad of researchers studying from different theoretical and practical perspectives. 
Many research institutions; associations and international networks have also been created based on UBC at their core.

Some examples include the Triple Helix Association (TH) and the University Industry Interaction Network (UIIN). These associations organize seminars and conferences that constitute unique vibrant forums where academics and practitioners discuss the newest advances in this field. Similarly, specific journals and conferences have emerged aiming at providing a forum for discussion. Some specific journals that clearly deal with this topic include: Research Policy, Technovation, Journal of Technology Transfer, Journal of Engineering and Technology Management, R\&D Management and the International Journal of Technology Management.

Given the amount of research generated around the different mechanisms through which to articulate technology transfer processes between universities and business, there is an urgent need for reviewing the state of the art from its theoretical inception, in the early 1980 s, to the present.

We had decided to start this analysis from 1980 due to the fact that in that year the Bayh-Dole Act was enacted in the USA, which allowed universities to appropriate patents derived from public funds. In the same line, researchers working on public funds were stipulated to disclose their inventions to the technology transfer office $[9,50]$.

This Act fostered the commercialization of university research $[38,42]$. It is important to note that since this relevant Act, other countries outside of the USA such as Denmark, Germany, Austria, and Norway have reformed their intellectual property laws by giving universities ownership of publicly funded inventions, similar to the Bayh-Dole Act. [64].

By using an extensive range of bibliometric indicators, in this study, we identify the most influential journals, authors, and papers.

We also analyse which countries and research institutions are taking a leading role in this particular field. The information was obtained from the Web of Science (WoS) database, considered one of the most relevant databases in the academic domain. Some prior studies have adopted a similar approach, but concentrate on specific geographical areas.
Had been presented a study based on joint scientific publications between universities and industry in the UK, covering two decades (19802000) [18]. Similarly, there is an analysis that examines public and private research collaboration between universities and industry in Italy for the period 2001-2003 [2]. In the same line, but without using bibliometric indicators, had been analysed academic articles in the field of UBC, starting in 1990 and ending in 2014 [5]. Our study differs from previous ones for considering the most current tools to represent a research area with bibliometric indicators, and for adopting a global geographical perspective [34, 53].

The remainder of the paper is organized as follows. We first describe the methodology. The next section, presents the results, including the most influential journals, the most cited papers, the most productive and influential authors, the main institutions in this area of knowledge and the most relevant countries. Next, we discuss the main implications. The paper ends with some concluding remarks alongside indicators for future works.

\section{Methodology}

The search process takes as a basis the Web of Science (WoS) database. Despite the fact that other databases could have been used (e.g. Scopus, EconLit, Google Scholar) we selected this database as it has been acknowledged to beof high quality and one of the main sources of citation information in the world $[67,53]$. WoS includes more than 15,000 journals and 50,000,000 articles that encompass all the known sciences [48]. Information is classified into research categories, research areas, articles, authors, journals, institutions, and countries.

Today WoS distinguishes 250 categories that are grouped in 150 areas. For the purpose of this study, the focus is given to the WoS Core Collection, which covers 12,000 of the most recognised journals worldwide as well as Open Access journals in the sciences, social sciences, arts, and humanities, with coverage since 1900. Despite The Social Science Citation Index (SSCI) have received some criticism about ideological bias in journals' inclusion, it could be just a result of chance [40]. 
Table 1. List of keywords in university business collaboration and technology transfer

\begin{tabular}{lc}
\hline Actors involved & $\begin{array}{c}\text { Technology transfer } \\
\text { agreement }\end{array}$ \\
\hline University Business & Collaboration \\
\hline University-Business & Cooperation \\
\hline $\begin{array}{l}\text { University-Industry or } \\
\text { University Industry }\end{array}$ & Partnership \\
\hline $\begin{array}{l}\text { Industry-Science or } \\
\text { Industry Science }\end{array}$ & Link \\
\hline $\begin{array}{l}\text { Science to Business or } \\
\text { Science 2 Business }\end{array}$ & Technology Transfer \\
\hline
\end{tabular}

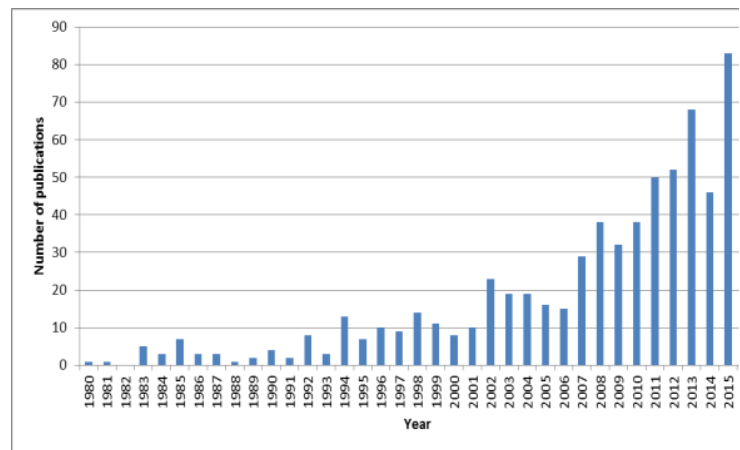

Fig. 1. Evolution of papers published by year in university business collaboration and technology transfer from 1980 to 2016

The study was done via the web, and it was consulted less of a quarter of the total journals indexed in SSCl. The first step in the search process was the identification of meaningful keywords that unequivocally return papers that fall within the topic of our interest: technology transfer links between academia and industry. We were therefore interested in papers that contained at least two different ideas: a collaboration or partnership agreement (mechanism articulating the technology transfer process), and the actors involved (industry and university).

Because literature has referred to these concepts using a variety of terms, we first elaborated a list containing all potential synonyms (see Table 1).
This process was indispensable to determine the inclusion/exclusion criteria to apply in the bibliometric study.

The search was conducted during July and August 2016. The inclusion criteria for accepting papers were: a) document type: article or review, b) language: English, c) timespan: all years, d) indexes: SCI-EXPANDED, SSCI, A\&HCl, CPCl-S, $\mathrm{CPCl}-\mathrm{SSH}$, and $\mathrm{ESCl}$. This research strategy returned an initial set of 696 records, from which 673 were journal articles and 23 reviews.

It is worth noting that these publications refer to the period comprising 1980 to 2016 (see Figure 1), coinciding with the enactment of the Bayh-Dole Act in 1980.This reform introduced important modifications to how universities could exploit new technologies and research developments created in the university setting, having significant political and management implications for all those involved in the commercialisation of university research results $[60,43]$. Aiming at identifying the most influential journals, the most relevant articles, the most productive authors, as well as the leading institutions and countries researching in this particular field, we used several key indicators for measuring the bibliographic material. The purpose is to give a general overview of the bibliographic material [14].

First, we relied on the citations/paper ratio, which permits to identify the most influential articles [48]. Second, we used the h-index a measure that integrates publications and citations in the same formulation, by connecting the number of papers $n$ that has received $n$ citations [34]. This index measures the productivity of a researcher and total impact of the papers.

Thus, researchers with a similar $\mathrm{h}$-index are comparable at the level of scientific impact, although their number of articles and citations differs. (e.g., if a researcher has an h-index of 50, it means that he has a set of 50 articles that have received at least 50 or more citations. The h-index can be utilised in authors, countries, journals, articles, and universities.

Thus, it allows making a holistic analysis of a certain field of research, taking into account several different items [11]. The Impact Factor (IF) for 2015 has been included in Table 3 to present the quality of each journal. 
Table 2. Twenty-five main categories according to the web of science core collection report

\begin{tabular}{|c|c|c|c|}
\hline Rank & Category & Number of records & $\%$ Of 696 records \\
\hline 1 & Management & 334 & 47.989 \\
\hline 2 & Planning development & 137 & 19.684 \\
\hline 3 & Engineering industrial & 105 & 15.086 \\
\hline 4 & Business & 89 & 12.787 \\
\hline 5 & $\begin{array}{l}\text { Operations research management } \\
\text { science }\end{array}$ & 70 & 10.057 \\
\hline 6 & Economics & 65 & 9.339 \\
\hline 7 & Information science library science & 63 & 9.052 \\
\hline 8 & Engineering multidisciplinary & 58 & 8.333 \\
\hline 9 & Education educational research & 56 & 8.046 \\
\hline 10 & $\begin{array}{l}\text { Computer science interdisciplinary } \\
\text { applications }\end{array}$ & 45 & 6.466 \\
\hline 11 & Geography & 27 & 3.879 \\
\hline 12 & Environmental studies & 27 & 3.879 \\
\hline 13 & Education scientific disciplines & 27 & 3.879 \\
\hline 14 & Multidisciplinary sciences & 26 & 3.736 \\
\hline 15 & Public administration & 20 & 2.874 \\
\hline 16 & Urban studies & 16 & 2.299 \\
\hline 17 & Engineering electrical electronic & 14 & 2.011 \\
\hline 18 & History philosophy of science & 10 & 1.437 \\
\hline 19 & Social sciences interdisciplinary & 9 & 1.293 \\
\hline 20 & $\begin{array}{l}\text { Computer science information } \\
\text { systems }\end{array}$ & 8 & 1.149 \\
\hline 21 & Social issues & 7 & 1.006 \\
\hline 22 & Materials science multidisciplinary & 7 & 1.006 \\
\hline 23 & Ethics & 7 & 1.006 \\
\hline 24 & Chemistry multidisciplinary & 7 & 1.006 \\
\hline 25 & Health care sciences services & 6 & 0.862 \\
\hline
\end{tabular}

Ranking is development according to percentage of University Business Collaboration (UBC) and Technology Transfer papers in the Journals published between 1980-2016 at Web of Science Core Collection. The total records found during this period were 696

The impact factor analyses the influence of a journal over a two-year period, dividing the total citations received in year $n-1$ and $n-2$ by the total number of articles published in year $n-1$ and $n-2$. The impact factor in recent years has received numerous criticisms because it has been argued the ease of manipulation of results through selfcitations or related techniques [19]. Impact Factor considers the two previous years. However; longer time periods of citations and/or sources could be considered, but then the indicator would not be current enough [29]. 


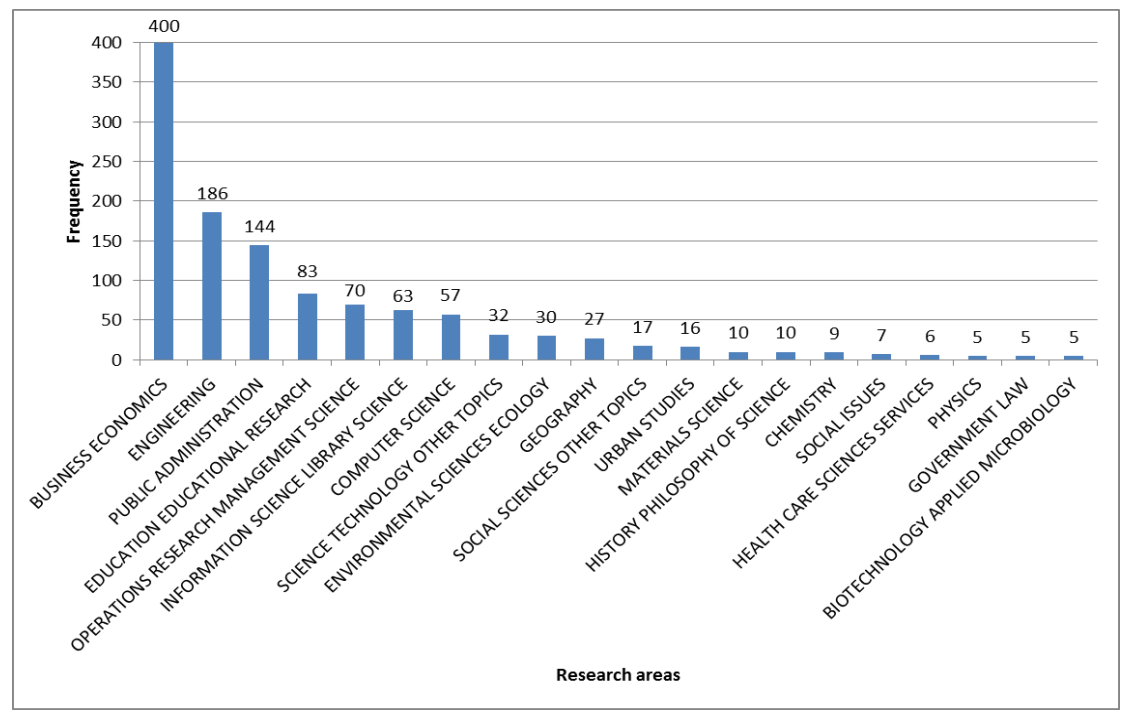

Fig. 2. Top-20 Research areas in university business collaboration and technology transfer from 1980 to 2016

The percentage of papers in UBC of any given journal (TP-UBC/TP) in Table 3 is also included. To evaluate the citation rate of papers in UBC, in Table 7, The countries information is classified according to citation structure with thresholds of, $>250,>100,>50$ citations.

In order to map the bibliometrical material we employed Science mapping. This science is considered a specific science, in which the different scientific fields are structured in a conceptual, intellectual and social mode [20]. Additionally, the study uses VOS viewer software that provides easy-to-interpret graphical representations of the bibliographic material and has the functionality to construct maps based on citation, co-citation co-authorship, bibliographic coupling and co-occurrence data [65, 47]. Bibliographic coupling takes place when two articles cite the same third article [39].

Co-occurrence identifies the most common keywords used in the articles.

This list of keywords generally can be founded on the first page of the paper [41]. Figure 3 and Figure 4 present the mapping of the most cited authors between 1980-2016 and 1917-1918. The mapping is focused on authors so we look for citation, co-citation, and co-authorship with a threshold of fifty cites and one paper.
Citation analysis counts the number of times that document $A$ cites document $B$ and vice versa [49]. Co-citation results when the study $A$ and study $B$ receive a citation from the same $C$ study [63]. Co-authorship identify the scientific output of researchers as well as their joint publications [46].

The graphical visualization is showed through network where the size of the node increases with the number of publications and the network connection the relationship between them. VOS is available free of charge, and more information about the program can be obtained at the following link: www.vosviewer.com.

Table 2 shows the research categories in which the 696 records fell. Only the top 25 research categories are displayed, however, they cover almost the entire sample (95.97\%). The category with the highest number of articles is Management (334 articles), followed by Development Planning (137 articles), Industrial Engineering (105 articles) and Business (89 articles).

Concerning the research areas, Figure 2 reveals that Business and Economics accounts for $57.47 \%$ of the total volume, followed by Engineering (26.72\%), Public administration (20.69\%), and Education \& Educational Research $(11.92 \%)$. Overall, these results mirror the Triple Helix model of university-industry-government relationships [27]. 
Table 3. Twenty most influential journals in university business collaboration and technology transfer

\begin{tabular}{|c|c|c|c|c|c|c|c|c|c|}
\hline $\mathbf{R}$ & Journal & H-UBC & $\begin{array}{l}\text { TC- } \\
\text { UBC }\end{array}$ & $\begin{array}{l}\text { TP- } \\
\text { UBC }\end{array}$ & $\%$ P-UBC & TP & TC & IF 2015 & $\mathbf{H}$ \\
\hline 1 & Research Policy & 39 & 5,271 & 91 & 13.075 & 3,026 & 116,959 & 3.470 & 155 \\
\hline 2 & Technovation & 15 & 677 & 31 & 4.454 & 1,933 & 29,328 & 2.243 & 68 \\
\hline 3 & $\begin{array}{l}\text { Journal of } \\
\text { Technology Transfer }\end{array}$ & 12 & 512 & 50 & 7.184 & 433 & 3,042 & 2.213 & 26 \\
\hline 4 & Scientometrics & 12 & 371 & 38 & 5.460 & 4,587 & 55,466 & 2.084 & 82 \\
\hline 5 & Higher Education & 10 & 209 & 21 & 3.017 & 3,602 & 24,583 & 1.207 & 59 \\
\hline 6 & $\begin{array}{l}\text { International Journal } \\
\text { of Technology } \\
\text { Management }\end{array}$ & 8 & 137 & 30 & 4.310 & 1,982 & 10,530 & 0.867 & 35 \\
\hline 7 & World Development & 6 & 179 & 6 & 0.862 & 5,844 & 100,326 & 2.438 & 116 \\
\hline 8 & $\begin{array}{l}\text { IEEE Transactions } \\
\text { on Engineering } \\
\text { Management }\end{array}$ & 6 & 115 & 6 & 0.862 & 2,024 & 26,011 & 1.454 & 61 \\
\hline 9 & $\begin{array}{l}\text { Technological } \\
\text { Forecasting and } \\
\text { Social Change }\end{array}$ & 5 & 62 & 9 & 1.293 & 4,013 & 33,163 & 2.678 & 65 \\
\hline 10 & R \& D Management & 5 & 107 & 9 & 1.293 & 1,972 & 19,145 & 1.190 & 61 \\
\hline 11 & $\begin{array}{l}\text { Industrial and } \\
\text { Corporate Change }\end{array}$ & 5 & 134 & 6 & 0.862 & 723 & 14,295 & 1.327 & 55 \\
\hline 12 & $\begin{array}{l}\text { European Planning } \\
\text { Studies }\end{array}$ & 4 & 45 & 12 & 1.724 & 1,645 & 10,874 & 1.056 & 39 \\
\hline 13 & $\begin{array}{l}\text { Technology Analysis } \\
\text { \& Strategic } \\
\text { Management }\end{array}$ & 4 & 53 & 10 & 1.437 & 1,105 & 9,903 & 0.845 & 41 \\
\hline 14 & $\begin{array}{l}\text { Papers in Regional } \\
\text { Science }\end{array}$ & 4 & 219 & 5 & 0.718 & 930 & 7,324 & 1.144 & 39 \\
\hline 15 & $\begin{array}{l}\text { Journal of } \\
\text { Engineering and } \\
\text { Technology } \\
\text { Management }\end{array}$ & 4 & 195 & 5 & 0.718 & 482 & 6,491 & 1.474 & 41 \\
\hline 16 & $\begin{array}{l}\text { International Journal } \\
\text { of Engineering } \\
\text { Education }\end{array}$ & 3 & 24 & 15 & 2.155 & 2,453 & 7,833 & 0.559 & 25 \\
\hline 17 & $\begin{array}{l}\text { Science and Public } \\
\text { Policy }\end{array}$ & 3 & 27 & 12 & 1.724 & 532 & 1,605 & 1.233 & 15 \\
\hline 18 & $\begin{array}{l}\text { Industry and } \\
\text { Innovation }\end{array}$ & 3 & 30 & 11 & 1.580 & 296 & 1,686 & 0.87 & 20 \\
\hline 19 & Research Evaluation & 3 & 53 & 10 & 1.437 & 475 & 3,661 & 1.467 & 26 \\
\hline 20 & $\begin{array}{l}\text { Science Technology } \\
\text { and Society }\end{array}$ & 2 & 13 & 6 & 0.862 & 119 & 124 & 0.231 & 6 \\
\hline
\end{tabular}

Abbreviations: R, rank; H-UBC, H-index only with University Business Collaboration (UBC) and Technology Transfer; TC-UBC, Total Citations of papers in the area of University-Business Collaboration and Technology Transfer; TP-UBC, Total Production of papers on the topic of University-Business Collaboration and Technology Transfer; \% P-UBC, percentage of papers published in a given journal in the specific topic of University-Business Collaboration and Technology Transfer; TP, Total number of papers; TC, Total number of citations; H, H-index; IF 2015 , impact factor for the year 2015. Journals are ranked according to the $\mathrm{H}$-index and percentage of TC-UBC. 
ISSN 2007-9737

1178 Claudia Olvera, Jasmina Berbegal-Mirabent, José M. Merigó

Table 4. Twenty-five most cited papers in in university business collaboration and technology transfer

\begin{tabular}{|c|c|c|c|c|c|c|}
\hline 7 & $\mathbf{J}$ & TC & Title & Author/s & Year & $C / Y$ \\
\hline 1 & $\mathrm{RP}$ & 379 & $\begin{array}{l}\text { Assessing the impact of organizational practices on the } \\
\text { relative productivity of university technology transfer offices: } \\
\text { an exploratory study }\end{array}$ & Siegel et al. & 2003 & 27.07 \\
\hline 2 & $\mathrm{RP}$ & 336 & $\begin{array}{l}\text { Technology transfer and public policy: a review of research } \\
\text { and theory }\end{array}$ & $\begin{array}{l}\text { Bozeman et } \\
\text { al. }\end{array}$ & 2000 & 19.76 \\
\hline 3 & $\mathrm{RP}$ & 303 & $\begin{array}{l}\text { The norms of entrepreneurial science: cognitive effects of the } \\
\text { new university-industry linkages }\end{array}$ & $\begin{array}{l}\text { Etzkowitz et } \\
\text { al. }\end{array}$ & 1998 & 15.95 \\
\hline 4 & $\mathrm{RP}$ & 240 & $\begin{array}{l}\text { Searching high and low: what types of firms use universities } \\
\text { as a source of innovation? }\end{array}$ & Laursen et al. & 2004 & 18.46 \\
\hline 5 & $\mathrm{RP}$ & 232 & $\begin{array}{l}\text { University-industry linkages in the UK: What are the factors } \\
\text { underlying the variety of interactions with industry? }\end{array}$ & D'Este et al. & 2007 & 23.2 \\
\hline 6 & IJMR & 200 & $\begin{array}{l}\text { University-industry relationships and open innovation: } \\
\text { Towards a research agenda }\end{array}$ & $\begin{array}{l}\text { Perkmann et } \\
\text { al. }\end{array}$ & 2007 & 20 \\
\hline 7 & $\mathrm{RP}$ & 193 & $\begin{array}{l}\text { Resources, capabilities, risk capital and the creation of } \\
\text { university spin-out companies }\end{array}$ & Lockett et al. & 2005 & 16.08 \\
\hline 8 & $\mathrm{RP}$ & 176 & $\begin{array}{l}\text { University patenting and its effects on academic research: The } \\
\text { emerging European evidence }\end{array}$ & Geuna et al. & 2006 & 16 \\
\hline 9 & $\mathrm{RP}$ & 172 & $\begin{array}{l}\text { Networks of inventors and the role of academia: An } \\
\text { exploration of Italian patent data }\end{array}$ & Balconi et al. & 2004 & 13.23 \\
\hline 10 & $\mathrm{RP}$ & 169 & $\begin{array}{l}\text { The role of academic technology transfer organizations in } \\
\text { improving industry science links }\end{array}$ & $\begin{array}{l}\text { Debackere et } \\
\text { al. }\end{array}$ & 2005 & 14.08 \\
\hline 11 & $\mathrm{RP}$ & 168 & $\begin{array}{l}\text { 'Technology transfer' and the research university: A search for } \\
\text { the boundaries of university-industry collaboration }\end{array}$ & Lee, Y.S. & 1996 & 8 \\
\hline 12 & MS & 167 & $\begin{array}{l}\text { A comparison of US and European university-industry } \\
\text { relations in the life sciences }\end{array}$ & $\begin{array}{l}\text { Owen-Smith } \\
\text { et al. }\end{array}$ & 2002 & 11.13 \\
\hline 13 & PRS & 160 & $\begin{array}{l}\text { The geographical and institutional proximity of research } \\
\text { Collaboration }\end{array}$ & Pond et al. & 2007 & 16 \\
\hline 14 & JETM & 160 & $\begin{array}{l}\text { Toward a model of the effective transfer of scientific } \\
\text { knowledge from academicians to practitioners: qualitative } \\
\text { evidence from the commercialization of university } \\
\text { technologies }\end{array}$ & Siegel et al. & 2004 & 12.31 \\
\hline 15 & $\mathrm{RP}$ & 152 & $\begin{array}{l}\text { Factors affecting university-industry R\&D projects: The } \\
\text { importance of searching, screening and signalling }\end{array}$ & Fontana et al. & 2006 & 13.82 \\
\hline 16 & $\mathrm{RP}$ & 150 & $\begin{array}{l}\text { Knowledge interactions between universities and industry in } \\
\text { Austria: sectoral patterns and determinants }\end{array}$ & $\begin{array}{l}\text { Schartinger, } \\
\text { et al. }\end{array}$ & 2002 & 10 \\
\hline 17 & JBV & 148 & $\begin{array}{l}\text { The effects of business-university alliances on innovative } \\
\text { output and financial performance: a study of publicly traded } \\
\text { biotechnology companies }\end{array}$ & George et al. & 2002 & 9.87 \\
\hline 18 & $\mathrm{RP}$ & 144 & $\begin{array}{l}\text { Bottom-up versus top-down policies towards the } \\
\text { commercialization of university intellectual property }\end{array}$ & $\begin{array}{l}\text { Goldfarb et } \\
\text { al. }\end{array}$ & 2003 & 10.29 \\
\hline 19 & IJIO & 142 & $\begin{array}{l}\text { R\&D cooperation between firms and universities. Some } \\
\text { empirical evidence from Belgian manufacturing }\end{array}$ & $\begin{array}{l}\text { Veugelers et } \\
\text { al. }\end{array}$ & 2005 & 11.83 \\
\hline 20 & $\mathrm{RP}$ & 136 & How effective are technology incubators? Evidence from Italy & $\begin{array}{l}\text { Colombo et } \\
\text { al. }\end{array}$ & 2002 & 9.07 \\
\hline 21 & $\mathrm{RP}$ & 121 & $\begin{array}{l}\text { Investigating the factors that diminish the barriers to } \\
\text { university-industry collaboration }\end{array}$ & Bruneel et al. & 2010 & 17.29 \\
\hline 22 & MS & 117 & $\begin{array}{l}\text { Equity and the technology transfer strategies of American } \\
\text { research universities }\end{array}$ & $\begin{array}{l}\text { Feldman et } \\
\text { al. }\end{array}$ & 2002 & 7.8 \\
\hline 23 & $\mathrm{RP}$ & 113 & $\begin{array}{l}\text { Analysing knowledge transfer channels between universities } \\
\text { and industry: To what degree do sectors also matter? }\end{array}$ & Bekkers et al. & 2008 & 12.56 \\
\hline 24 & $\mathrm{RP}$ & 96 & $\begin{array}{l}\text { Academic engagement and commercialisation: A review of the } \\
\text { literature on university-industry relations }\end{array}$ & $\begin{array}{l}\text { Perkmann et } \\
\text { al. }\end{array}$ & 2013 & 24 \\
\hline 25 & JEG & 88 & $\begin{array}{l}\text { Innovation, spillovers and university-industry collaboration: an } \\
\text { extended knowledge production function approach }\end{array}$ & Ponds et al. & 2010 & 12.57 \\
\hline
\end{tabular}

Abbreviations: R, rank; J, Journal; TC, Total Citations; Year, Year of Publication; C/Y, Average of citations per year. Rank according to the results from WoS Core Collection for the period 1980-2016, with 696 records: Sum of Times Cited 11553; Average Citations per item 16.6; H-index 51. RP, Research Policy; IJMR, International Journal of Management Reviews; MS, Management Science; PRS, Papers in Regional Science; JETM, Journal of Engineering and Technology Management; JBV, Journal of Business Venturing; IJIO, International Journal of Industrial Organization; JEG, Journal of Economic Geography.

Indeed, the most recurrent categories are business nistration (government). (industry), education (university) and public admi- 


\section{Results}

This Section summarises the main results of this paper. First, we provide a comprehensive analysis of the most influential journals in the domain of technology transfer processes aimed at fostering university-business collaborations. The analysis is limited to the top-20 journals. Second, following a similar strategy, we concentrate on the most cited articles. Next, we focus on the most prolific authors. Lastly, we study which institutions and countries act as drivers in this particular field.

\subsection{Most Influential Journals}

The most influential journals were selected according to the $\mathrm{h}$-index and the percentage of publications during the period 1980-2016. The impact factor was also included as an indicator of the relative importance of the journal in its area. Information was collected from the Journal Citation Reports.

This indicator is computed by dividing the number of citations received during two previous years by the total number of articles published in the same period.

The 20 most influential journals in this field are shown in Table 3. However, as it can be inferred, the most representative ones are those in the top 10 , because their impact factor, $\mathrm{h}$-index and total citations is relatively high compared to the total volume. This list includes: Research Policy, Technovation, Journal of Technology Transfer, Scientometrics, Higher Education, International Journal of Technology Management, World Development, IEEE Transactions on Engineering Management, Technological Forecasting and Social Change and R\&D Management. As will be discussed later, these journals are also the target journal outlets where the most productive authors publish their research.

\subsection{Most Cited Articles}

In order to rank journals, we used the number of citations. This indicator serves as proxy for the relevance and impact of an article within the academic community. A total of 25 articles were selected.
The citations/papers ratio was also used to complement the information for relevance [48]. Table 4 displays the list of top articles. Remarkably, the majority of these papers leave published in Research Policy. Authors that appear

in top positions are: D.S. Siegel, D. Waldman, A. Link, B. Bozeman, H. Etzkowitz, K. Lausen, A. Salter, P. D'Este, P. Patel, M. Perkmann, and K. Wash, all with more than 200 citations.

The most cited papers were published during the first decade of the beginning of the millennium. As it will be later shown in Tables 5 and 6 , most cited articles are authored by those authors listed as the most influential ones, and belong to leading institutions in this area.

For instance, Perkmann and Salter are affiliated to the Imperial College London (UK); Cassiman, Debackere and Veugelers to KU Leuven (Belgium); Frenken and Bekkers to the Eindhoven University of Technology (The Netherlands); D'Angelo, Abramo, and Solazzi to the University of Rome Tor Vergata (Italy) and Freitas and Geuna to University of Turin (Italy).

\subsection{Most Productive Authors}

Table 5 presents a list of the 25 most productive authors in UBC. As shown, Perkmann leads the ranking with 10 papers; D'Este and Muscio tied with 8 papers each, followed by Salter and Leydesdorff, with 7 publications. Looking at the citations record, Siegel achieves the highest number (687). This figure suggests that despite not being the most productive author in this area, his research is impactful, as his works have been widely cited by other authors.

D'Este obtains second position in terms of citations (641) followed by Perkmann (561), Geuna (523) and Salter (521). With the objective to show a global view, some columns were added displaying information about the total citations and number of papers published beyond UBC production (also recorded in WoS). We also include the number of top papers of each of the authors listed in the table according to the Web of Science Essential Science indicators. 
Table 5. Twenty-five most productive authors in university business collaboration and technology transfer.

\begin{tabular}{|c|c|c|c|c|c|c|c|c|c|c|}
\hline $\mathbf{R}$ & Author/s & Affiliation & Country & TP & TC & $\mathbf{H}$ & T25 & TP & TC & ES \\
\hline 1 & $\begin{array}{l}\text { Perkmann, } \\
\text { M. }\end{array}$ & Imperial College London & England & 10 & 561 & 7 & 5 & 17 & 567 & 2 \\
\hline 2 & D'Este, P. & $\begin{array}{l}\text { Universitat Politècnica de } \\
\text { València }\end{array}$ & Spain & 8 & 641 & 7 & 4 & 19 & 591 & 4 \\
\hline 3 & Muscio, A. & University of Foggia & Italy & 8 & 123 & 4 & 1 & 0 & 0 & 0 \\
\hline 4 & Salter, A. & Imperial College London & England & 7 & 521 & 5 & 4 & 62 & 1,763 & 4 \\
\hline 5 & $\begin{array}{l}\text { Leydesdorff, } \\
\text { L. }\end{array}$ & University of Amsterdam & $\begin{array}{l}\text { The } \\
\text { Netherlands }\end{array}$ & 7 & 222 & 5 & 1 & 163 & 3,282 & 13 \\
\hline 6 & Geuna, A. & University of Turin & Italy & 6 & 523 & 5 & 4 & 17 & 581 & 2 \\
\hline 7 & Brostrom, A. & $\begin{array}{l}\text { Royal Institute of } \\
\text { Technology }\end{array}$ & Sweden & 6 & 156 & 5 & 1 & 115 & 1,867 & 5 \\
\hline 8 & Park, H.W. & Yeungnam University & South Korea & 6 & 109 & 3 & 1 & 0 & 0 & 0 \\
\hline 9 & Frenken, $\mathrm{K}$. & $\begin{array}{l}\text { Eindhoven University of } \\
\text { Technology }\end{array}$ & $\begin{array}{c}\text { The } \\
\text { Netherlands }\end{array}$ & 5 & 265 & 3 & 2 & 41 & 1,710 & 11 \\
\hline 10 & $\begin{array}{l}\text { Freitas, } \\
\text { I.M.B. }\end{array}$ & University of Turin & Italy & 5 & 149 & 4 & 1 & 0 & 0 & 0 \\
\hline 11 & $\begin{array}{l}\text { D'Angelo, } \\
\text { C.A. }\end{array}$ & $\begin{array}{l}\text { University of Rome Tor } \\
\text { Vergata }\end{array}$ & Italy & 5 & 83 & 5 & 0 & 83 & 873 & 1 \\
\hline 12 & Abramo, G. & $\begin{array}{l}\text { University of Rome Tor } \\
\text { Vergata }\end{array}$ & Italy & 5 & 83 & 5 & 0 & 77 & 793 & 1 \\
\hline 13 & $\begin{array}{l}\text { Fernandez- } \\
\text { Esquinas, M. }\end{array}$ & CSIC & Spain & 5 & 25 & 3 & 0 & 0 & 0 & 0 \\
\hline 14 & Siegel, D.S. & University at Albany & USA & 4 & 687 & 4 & 4 & 103 & 3,524 & 10 \\
\hline 15 & Veugelers, R. & KU Leuven & Belgium & 4 & 381 & 4 & 2 & 30 & 794 & 1 \\
\hline 16 & Walsh, K. & $\begin{array}{l}\text { Georgia Institute of } \\
\text { Technology }\end{array}$ & USA & 4 & 339 & 4 & 3 & 0 & 0 & 0 \\
\hline 17 & $\begin{array}{l}\text { Debackere, } \\
\text { K. }\end{array}$ & KU Leuven & Belgium & 4 & 277 & 4 & 1 & 29 & 760 & 0 \\
\hline 18 & Cassiman, B. & KU Leuven & Belgium & 4 & 191 & 4 & 1 & 13 & 618 & 2 \\
\hline 19 & Bekkers, R. & $\begin{array}{l}\text { Eindhoven University of } \\
\text { Technology }\end{array}$ & $\begin{array}{c}\text { The } \\
\text { Netherlands }\end{array}$ & 4 & 132 & 2 & 1 & 42 & 572 & 1 \\
\hline 20 & Tartari, V. & University of Bath & England & 4 & 119 & 2 & 1 & 0 & 0 & 0 \\
\hline 21 & McKelvey, M. & University of Gothenburg & Sweden & 4 & 110 & 3 & 1 & 0 & 0 & 0 \\
\hline 22 & Solazzi, M. & $\begin{array}{l}\text { University of Rome Tor } \\
\text { Vergata }\end{array}$ & Italy & 4 & 74 & 4 & 0 & 0 & 0 & 0 \\
\hline 23 & Welsh, R. & Clarkson University & USA & 4 & 59 & 2 & 0 & 45 & 2,492 & 4 \\
\hline 24 & Biscotti, D. & $\begin{array}{l}\text { University of California } \\
\text { Davis }\end{array}$ & USA & 4 & 59 & 2 & 0 & 0 & 0 & 0 \\
\hline 25 & Thune, $\mathrm{T}$. & University of Oslo & Norway & 4 & 43 & 4 & 0 & 0 & 0 & 0 \\
\hline
\end{tabular}

Abbreviations: R, rank; H-UBC; H-index only with University Business Collaboration (UBC) and Technology Transfer; TC-UBC and TP-UBC, Total Citations (TC) and Total Production (TP) in UBC; T25, number of papers in the top 25 list shown in Table 4; TP and TC, total papers and total citations in all publications indexed in WoS Essential Science Indicators for the past 2 years; ESI, top 1\% papers of WoS (past 2 years).

Computación y Sistemas, Vol. 22, No. 4, 2018, pp. 1171-1190

doi: 10.13053/CyS-22-4-3101 


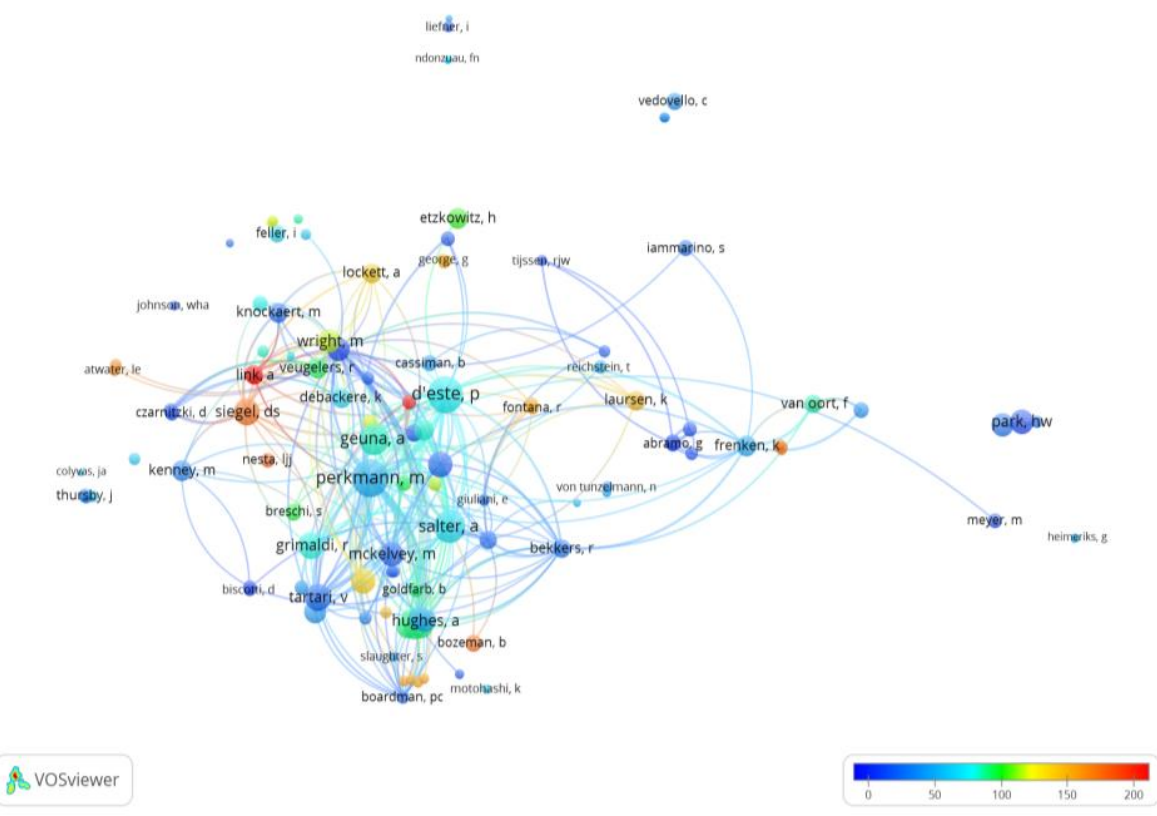

Fig. 3. The Most cited authors from 1980 to 2016. Colours indicate the citation impact of different authors, and the size of the node, the productivity of them. The link width shows the citations frequency between authors

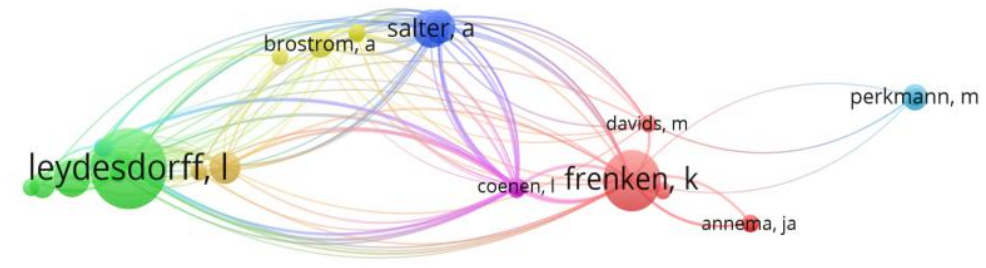

\section{\& Vosviewer}

Fig. 4. The most cited authors from 2017-2018. Colours indicate the citation impact of different authors, and the size of the node, the productivity of them. The link width shows the citations frequency between authors

All these columns provide meaningful information on how influential and active an author is.

We believe it is relevant for the reader to know whether the authors concentrate their research efforts on UBC or have made important contributions in other research areas.
This is the case with Leydesdorff (163 papers in WoS and 13 top papers), Brostrom (115 papers in WoS, and 5 top papers), Siegel (103 papers in WoS, 10 top papers), D'Angelo (83 papers in WoS, 1 top paper), Abramo (77 papers in WoS, 1 top paper), Salter (62 papers in WoS, 4 top papers) and Welsh (45 papers in WoS, 4 top papers). 
Table 6. Most influential institutions in university business collaboration and technology transfer

\begin{tabular}{|c|c|c|c|c|c|c|c|c|c|c|c|}
\hline $\mathbf{R}$ & Institution & Country & TP-UBC & $\begin{array}{l}\text { TC- } \\
\text { UBC }\end{array}$ & $\begin{array}{c}\mathrm{H}- \\
\text { UBC }\end{array}$ & $\begin{array}{c}\text { TP } \\
(Y-10)\end{array}$ & $\begin{array}{c}\mathrm{TC} \\
(\mathrm{Y}-10)\end{array}$ & H & $\begin{array}{c}\text { TP } \\
(\mathrm{J}-10)\end{array}$ & $\begin{array}{c}\text { TC } \\
(\mathrm{J}-10)\end{array}$ & $\mathbf{H}$ \\
\hline 1 & CSIC Spain & Spain & 20 & 511 & 10 & 20 & 511 & 10 & 11 & 428 & 8 \\
\hline 2 & KU Leuven & Belgium & 17 & 609 & 10 & 13 & 233 & 6 & 9 & 395 & 7 \\
\hline 3 & $\begin{array}{l}\text { Imperial } \\
\text { College } \\
\text { London }\end{array}$ & England & 16 & 912 & 12 & 14 & 646 & 10 & 9 & 743 & 8 \\
\hline 4 & $\begin{array}{l}\text { University of } \\
\text { Sussex }\end{array}$ & England & 13 & 859 & 10 & 11 & 804 & 8 & 8 & 681 & 6 \\
\hline 5 & $\begin{array}{l}\text { Universitat } \\
\text { Politècnica de } \\
\text { València }\end{array}$ & Spain & 13 & 469 & 8 & 13 & 469 & 8 & 9 & 400 & 6 \\
\hline 6 & $\begin{array}{l}\text { University of } \\
\text { London }\end{array}$ & England & 12 & 173 & 5 & 10 & 169 & 5 & 2 & 58 & 2 \\
\hline 7 & $\begin{array}{l}\text { University of } \\
\text { Cambridge }\end{array}$ & England & 11 & 249 & 7 & 8 & 197 & 5 & 6 & 195 & 5 \\
\hline 8 & $\begin{array}{l}\text { Penn State } \\
\text { University }\end{array}$ & USA & 10 & 209 & 5 & 7 & 65 & 3 & 4 & 66 & 4 \\
\hline 9 & $\begin{array}{l}\text { University of } \\
\text { Tokyo }\end{array}$ & Japan & 9 & 179 & 6 & 5 & 85 & 4 & 4 & 143 & 4 \\
\hline 10 & $\begin{array}{l}\text { University of } \\
\text { Manchester }\end{array}$ & England & 9 & 82 & 4 & 7 & 48 & 3 & 3 & 40 & 2 \\
\hline 11 & $\begin{array}{l}\text { University of } \\
\text { California } \\
\text { Davis }\end{array}$ & USA & 9 & 271 & 6 & 9 & 271 & 6 & 9 & 271 & 6 \\
\hline 12 & $\begin{array}{l}\text { Copenhagen } \\
\text { Business } \\
\text { School }\end{array}$ & Denmark & 9 & 473 & 6 & 8 & 231 & 5 & 7 & 418 & 5 \\
\hline 13 & $\begin{array}{l}\text { University of } \\
\text { North Carolina }\end{array}$ & USA & 8 & 592 & 5 & 1 & 3 & 1 & 3 & 409 & 3 \\
\hline 14 & $\begin{array}{l}\text { University of } \\
\text { Foggia }\end{array}$ & Italy & 8 & 124 & 4 & 8 & 124 & 4 & 2 & 11 & 1 \\
\hline 15 & $\begin{array}{l}\text { Loughborough } \\
\text { University }\end{array}$ & England & 8 & 341 & 4 & 8 & 341 & 4 & 2 & 75 & 2 \\
\hline 16 & $\begin{array}{l}\text { Georgia } \\
\text { Institute of } \\
\text { Technology }\end{array}$ & USA & 8 & 432 & 5 & 8 & 432 & 5 & 6 & 421 & 4 \\
\hline 17 & $\begin{array}{l}\text { Bocconi } \\
\text { University }\end{array}$ & Italy & 8 & 418 & 8 & 6 & 236 & 6 & 6 & 389 & 6 \\
\hline 18 & $\begin{array}{l}\text { University of } \\
\text { Nottingham }\end{array}$ & England & 7 & 809 & 5 & 4 & 164 & 2 & 6 & 737 & 4 \\
\hline 19 & $\begin{array}{l}\text { University of } \\
\text { Amsterdam }\end{array}$ & $\begin{array}{c}\text { The } \\
\text { Netherlands } \\
\end{array}$ & 7 & 222 & 5 & 7 & 809 & 5 & 2 & 87 & 2 \\
\hline 20 & $\begin{array}{l}\text { Royal Institute } \\
\text { of Technology }\end{array}$ & Sweden & 7 & 161 & 5 & 7 & 161 & 5 & 4 & 148 & 4 \\
\hline 21 & CNRS France & France & 7 & 44 & 4 & 6 & 44 & 4 & 2 & 19 & 2 \\
\hline 22 & $\begin{array}{l}\text { Yeungnam } \\
\text { University }\end{array}$ & $\begin{array}{l}\text { South } \\
\text { Korea }\end{array}$ & 6 & 109 & 3 & 6 & 109 & 3 & 2 & 87 & 2 \\
\hline 23 & $\begin{array}{l}\text { University of } \\
\text { Utrecht }\end{array}$ & $\begin{array}{c}\text { The } \\
\text { Netherlands }\end{array}$ & 6 & 321 & 6 & 6 & 321 & 6 & 2 & 49 & 2 \\
\hline 24 & $\begin{array}{l}\text { University of } \\
\text { California } \\
\text { Berkeley } \\
\end{array}$ & USA & 6 & 106 & 4 & 5 & 103 & 4 & 6 & 106 & 4 \\
\hline 25 & $\begin{array}{l}\text { Newcastle } \\
\text { University }\end{array}$ & England & 6 & 37 & 3 & 6 & 37 & 3 & 0 & 0 & 0 \\
\hline
\end{tabular}

Abbreviations: R, rank; H-UBC, H-index only with University Business Collaboration (UBC) and Technology Transfer; TC-UBC and TP-UBC, Total Citations and papers only with UBC; TP-UBC10, TC-UBC10 and H-UBC10; Total Papers and citations, and H-index by institutions in the last 10 years in UBC; TP-UBC (J-10), TC-UBC (J-10) and H-UBC (J-10), Total Papers, citations and H-index in UBC in the first 10 Journal shown in the Table 3. 10 journals include Higher Education, IEEE Transactions on Engineering Management, International Journal of Technology Management, Journal of Technology Transfer, R\&D Management, Research Policy, Scientometrics, Technological Forecasting and Social Change, Technovation, and World Development. 
Table 7. Most productive countries in university business collaboration and technology transfer.

\begin{tabular}{|c|c|c|c|c|c|c|c|c|c|c|c|}
\hline $\mathbf{R}$ & Country & $\begin{array}{l}\text { TP. } \\
\text { UBC }\end{array}$ & $\begin{array}{c}\% \text { Of } \\
696 \\
\text { records }\end{array}$ & $\begin{array}{l}\text { TC- } \\
\text { UBC }\end{array}$ & $\begin{array}{c}\mathrm{H}- \\
\text { UBC }\end{array}$ & $\begin{array}{l}>250 \\
\text { UBC }\end{array}$ & $\begin{array}{l}>100 \\
\text { UBC }\end{array}$ & $\begin{array}{l}>50 \\
\text { UBC }\end{array}$ & $\begin{array}{c}\text { TP- } \\
\text { UBC } \\
(Y-10)\end{array}$ & $\begin{array}{c}\text { TC- } \\
\text { UBC } \\
(Y-10)\end{array}$ & $\begin{array}{c}\mathrm{H}- \\
\text { UBC } \\
(\mathrm{Y}-10)\end{array}$ \\
\hline 1 & USA & 190 & 27.30 & 4043 & 31 & 3 & 6 & 7 & 97 & 1,369 & 22 \\
\hline 2 & England & 103 & 14.80 & 3442 & 30 & 1 & 8 & 11 & 84 & 2,179 & 23 \\
\hline 3 & Italy & 63 & 9.05 & 1477 & 16 & 0 & 4 & 5 & 57 & 976 & 15 \\
\hline 4 & Spain & 50 & 7.18 & 926 & 14 & 0 & 2 & 3 & 45 & 668 & 12 \\
\hline 5 & $\begin{array}{l}\text { The } \\
\text { Netherlands }\end{array}$ & 44 & 6.32 & 980 & 18 & 0 & 2 & 4 & 40 & 871 & 16 \\
\hline 6 & Germany & 37 & 5.32 & 600 & 12 & 0 & 1 & 2 & 31 & 365 & 10 \\
\hline 7 & Japan & 34 & 4.89 & 414 & 11 & 0 & 0 & 1 & 23 & 252 & 9 \\
\hline 8 & Canada & 30 & 4.31 & 253 & 8 & 0 & 0 & 0 & 19 & 154 & 8 \\
\hline 9 & South Korea & 29 & 4.17 & 245 & 9 & 0 & 0 & 1 & 25 & 225 & 8 \\
\hline 10 & France & 29 & 4.17 & 532 & 11 & 0 & 1 & 2 & 25 & 524 & 11 \\
\hline 11 & Australia & 28 & 4.02 & 305 & 7 & 0 & 1 & 0 & 21 & 81 & 6 \\
\hline 12 & Belgium & 27 & 3.88 & 916 & 15 & 0 & 2 & 4 & 22 & 465 & 10 \\
\hline 13 & China & 26 & 3.74 & 104 & 6 & 0 & 0 & 0 & 26 & 103 & 6 \\
\hline 14 & Sweden & 24 & 3.45 & 425 & 9 & 0 & 1 & 1 & 19 & 242 & 7 \\
\hline 15 & Denmark & 16 & 2.30 & 510 & 7 & 0 & 2 & 1 & 15 & 268 & 6 \\
\hline 16 & Taiwan & 13 & 1.89 & 68 & 4 & 0 & 0 & 0 & 12 & 67 & 4 \\
\hline 17 & Switzerland & 11 & 1.58 & 113 & 5 & 0 & 0 & 0 & 10 & 95 & 4 \\
\hline 18 & Ireland & 11 & 1.58 & 56 & 5 & 0 & 0 & 0 & 10 & 55 & 5 \\
\hline 19 & Norway & 10 & 1.44 & 58 & 4 & 0 & 0 & 0 & 10 & 58 & 4 \\
\hline 20 & Finland & 10 & 1.44 & 133 & 5 & 0 & 0 & 1 & 9 & 115 & 5 \\
\hline 21 & Singapore & 9 & 1.29 & 60 & 3 & 0 & 0 & 0 & 7 & 48 & 3 \\
\hline 22 & Scotland & 8 & 1.15 & 117 & 5 & 0 & 0 & 1 & 6 & 43 & 4 \\
\hline 23 & Portugal & 8 & 1.15 & 131 & 3 & 0 & 0 & 1 & 7 & 49 & 3 \\
\hline 24 & India & 7 & 1.01 & 18 & 2 & 0 & 0 & 0 & 4 & 6 & 1 \\
\hline 25 & Hungary & 7 & 1.01 & 99 & 3 & 0 & 0 & 1 & 6 & 48 & 3 \\
\hline
\end{tabular}

Abbreviations: R, rank; H-UBC, H-index only with University Business Collaboration (UBC) and Technology Transfer; TC-UBC and TP-UBC, Total Citations and Papers only with UBC; $>250,>100$, >50, number of papers with more than 250,100 and 50 citations in UBC; TP-10, TC-10, and H-10,

Total Papers, Total Citations and $\mathrm{H}$-index in the last 10 years in UBC.

\subsection{Evolution of Productive Authors between 2017-2018}

To study the evolution of UBC field during the period between 2017-2018 ten authors with the highest presence and influence were chosen to compare their scientific contribution over a period from the last two years, (from January 2017 to February 2018).

In order to analyse this data set, we have used Web of Science (WoS) and Google Scholar databases. We selected those databases as they have been acknowledged to be of high quality and one of the primary sources of citation information 
in the world $[67,53]$. For the searching process, we focus on the total number of articles and the total number of citations of each author in both databases.

Table 8 presents the Evolution of 10 Most productive authors between 2017-2018. As we can see, Leydesdorff, is the most productive author with 15 papers; Frenken, 9 papers, Salter 4 and Muscio, 3 followed by Perkmann, Brostrom, Freitas, with 2 publications and D'Este with 1 article. Finally, Geuna and Park have not published papers during this period in spite of those authors had been very active the previous years. Looking at the citations records, we observed that Frenken and Leydesdorff have received more citations in WoS with 9 and 15 new publications each. The leading authors in Google Scholar also are Frenken, with 21 papers and 106 citations and Leydesdorff, with 20 articles and 80 quotes.

To provide a complete picture of the results, we compare the information found in WoS database to that of Google Scholar and both are quite similar. In general, most of the authors present an increase in papers and citations in Google Scholar database due to it includes papers, books and conference proceedings as well. Especially in the case of Leydesdorff and Frenken who have also made contributions in other areas and show significative increments. To compare the 2016 and 2018 rankings of the most productive authors, Table 9 summarises and show the main changes. Note that D'Este with one article and Park and Geuna with not publications are the authors lost positions in the classification. On the other hand, Leydesdorff and Frenken jumped up places due to the number of papers published and citations obtained. Most authors kept their position in the ranking.

It is worth noting that of 9 of the ten leading authors in UBC field are from Europe; this could mirror the interest of European researchers in the market application of their inventions through the engagement with the industry.

In order to complement the information of the most productive authors (Table 5) and their evolution (Table 8), we mapped the bibliographic material using concepts such as citation, cocitation and co-authorship with a threshold of fifty cites and one paper. Figure 3 and Figure 4 show the social network and identify their professional ties between them.

As we can see, the typology of network showed in Figure 3, and Figure 4 follow a power-law connectivity distribution, "it implies that most of the nodes have only a few links, held together by a few highly connected hubs" [4].

Figure 3 shows Perkmann with the most massive network; He keeps links with 120 authors of a sample of 134. Perkmann, as the central hub in this network, takes part in many representative clusters who hold the network connected. i.e. (Perkmann, Grimaldi, Tartari and Boardman), (Perkmann, D’Este, Salter, Geuna, Muscio and Frenken) and (Perkmann, Tartari, Etzkowitz). This strong connections confirms why Perkmann is the most recognised author in the UBC field.

Figure 4 shows, Leydesdorff, Frenken, Salter, Brostrom and Perkmann as important names for the period of 2017-2018.

In this period Leydesdorff and Frenken appear as the authors with more connections due to higher productivity in the last two years.

\subsection{Leading Institutions}

Table 6 presents the list of the leading institutions publishing papers in the field of UBC. They are ranked according to the ten journals with most influence by using the $\mathrm{H}$-index obtained (see Table 3 ). We have also considered the total volume of publications for the period under analysis (since 1980 ) as well as the production over the last 10 years. The Consejo Superior de Investigaciones Científicas (CSIC) leads the ranking with 20 papers, all of them published in the last 10 years, and more than half of them (11) were published in the 10 most influential journals in this area.

KU Leuven is in second position with 17 papers, followed by the Imperial College of London (16 papers). It is remarkable the leading role of UK institutions. Adding the citations received by three of them (Imperial College, University of Sussex and University of Nottingham) they account for 2,580citations.

The relevant role of $\mathrm{KU}$ Leuven as a leading centre in this area is based on the results obtained by the study elaborated by Debackere and Veugelers [24]. These authors report that among Belgian universities, KU Leuven was the one 
Table 8. Evolution of 10 most productive authors in UBC between 2017-2018 according to Web of Science and

\begin{tabular}{|c|c|c|c|c|c|c|c|c|c|c|c|c|}
\hline $\mathbf{R}$ & Author & Affiliation & C & $\begin{array}{l}\text { TP. } \\
\text { UBC } \\
\text { WoS } \\
2016\end{array}$ & $\begin{array}{l}\text { TC- } \\
\text { UBC } \\
\text { WoS } \\
2016\end{array}$ & $\begin{array}{l}\text { H- } \\
\text { UBC } \\
\text { WoS } \\
2016\end{array}$ & $\begin{array}{l}\text { TP. } \\
\text { UBC } \\
\text { WoS } \\
17-18\end{array}$ & $\begin{array}{l}\text { TC- } \\
\text { UBC } \\
\text { WoS } \\
17-18\end{array}$ & $\begin{array}{c}\text { H- } \\
\text { UBC } \\
\text { WoS } \\
17-18\end{array}$ & $\begin{array}{c}\text { TP-G } \\
\text { Scholar } \\
17-18\end{array}$ & $\begin{array}{c}\text { TC-G } \\
\text { Scholar } \\
17-18\end{array}$ & $\begin{array}{c}\text { H-G } \\
\text { Scholar } \\
17-18\end{array}$ \\
\hline 1 & $\begin{array}{l}\text { Perkmann, } \\
\text { M. }\end{array}$ & $\begin{array}{l}\text { Imperial } \\
\text { College } \\
\text { London }\end{array}$ & UK & 10 & 561 & 7 & 2 & 1 & 1 & 3 & 0 & 0 \\
\hline 2 & D'Este, P. & $\begin{array}{c}\text { Universitat } \\
\text { Politècnica } \\
\text { de } \\
\text { València }\end{array}$ & ES & 8 & 641 & 7 & 1 & 0 & 0 & 5 & 1 & 1 \\
\hline 3 & Muscio, A. & $\begin{array}{l}\text { University } \\
\text { of Foggia }\end{array}$ & IT & 8 & 123 & 4 & 3 & 0 & 0 & 4 & 1 & 1 \\
\hline 4 & Salter, A. & $\begin{array}{l}\text { Imperial } \\
\text { College } \\
\text { London }\end{array}$ & UK & 7 & 521 & 5 & 4 & 4 & 1 & 6 & 13 & 1 \\
\hline 5 & $\begin{array}{l}\text { Leydesdorff, } \\
\text { L. }\end{array}$ & $\begin{array}{l}\text { University } \\
\text { of } \\
\text { Amsterdam }\end{array}$ & $\mathrm{NL}$ & 7 & 222 & 5 & 15 & 13 & 2 & 20 & 80 & 6 \\
\hline 6 & Geuna, A. & $\begin{array}{l}\text { University } \\
\text { of Turin }\end{array}$ & IT & 6 & 523 & 5 & 0 & 0 & 0 & 1 & 0 & 0 \\
\hline 7 & Brostrom, A. & $\begin{array}{c}\text { Royal } \\
\text { Institute of } \\
\text { Technology }\end{array}$ & SE & 6 & 156 & 5 & 2 & 2 & 1 & 3 & 5 & 2 \\
\hline 8 & Park, H.W. & $\begin{array}{l}\text { Yeungnam } \\
\text { University }\end{array}$ & $\mathrm{KR}$ & 6 & 109 & 3 & 0 & 0 & 0 & 0 & 0 & 0 \\
\hline 9 & Frenken, K. & $\begin{array}{l}\text { Eindhoven } \\
\text { University } \\
\text { of } \\
\text { Technology }\end{array}$ & $\mathrm{NL}$ & 5 & 265 & 3 & 9 & 17 & 3 & 21 & 106 & 6 \\
\hline 10 & $\begin{array}{l}\text { Freitas, } \\
\text { I.M.B. }\end{array}$ & $\begin{array}{l}\text { University } \\
\text { of Turin }\end{array}$ & IT & 5 & 149 & 4 & 2 & 0 & 0 & 3 & 29 & 2 \\
\hline
\end{tabular}

Abbreviations: R, rank; C, Country; H-UBC; H-index only with University Business Collaboration (UBC) and Technology Transfer; TC-UBC and TPUBC, Total Citations (TC) and Total Production (TP) in UBC indexed in Web of Science. Essential Science Indicators: TP and TC, total papers and total citations in all publications indexed in Google Scholar during the period from January 2017 to February 2018. NL, The Netherlands; UK, United Kingdom; IT, Italy; ES, Spain; SE, Sweden; KR, South Korea.

receiving the largest investment for $R \& D$ activities. In fact, data corroborate that this university is very active in terms of granted patents and spin-offs, compared to the average level of European universities. This high volume of output line up with the mission statement of the university, which posits that KU Leuven is: "an academic institution where research and knowledge transfer are both essential and complementary", (KU Leuven, Mission Statement, 2002).

Therefore, the inclusion of this university in this list is not by accident. Likewise, three of the most prolific authors are affiliated to KU Levuen, corroborating that this university is highly productive in terms of technology transfer outputs but also there is a critical mass of researchers investigating UBC practice.

\subsection{Analysis by Country}

Lastly, in this part, we analyse the geographical distribution of the scientific production on UBC. The centre of attention is on articles published by the Universities or research institutions and signed by the team inside the country without taking into account the researcher nationality. Table 7 
Table 9. Evolution of 10 most productive authors in UBC between 1916-2018, according to Web of Science database

\begin{tabular}{|c|c|c|c|c|c|c|}
\hline $\mathbf{R}$ & Author & Affiliation & Country & $\begin{array}{c}\text { TP-UBC } \\
\text { WoS } \\
(16-18)\end{array}$ & $\begin{array}{c}\text { TC-UBC } \\
\text { WoS } \\
(16-18)\end{array}$ & $\begin{array}{c}\text { H-UBC } \\
\text { WoS } \\
(16-18)\end{array}$ \\
\hline 1 & $\begin{array}{l}\text { Leydesdorff, } \\
\text { L. }\end{array}$ & University of Amsterdam & $\mathrm{NL}$ & 22 & 235 & 5 \\
\hline 2 & Frenken, $\mathrm{K}$. & $\begin{array}{c}\text { Eindhoven University of } \\
\text { Technology }\end{array}$ & $\mathrm{NL}$ & 14 & 282 & 3 \\
\hline 3 & $\begin{array}{l}\text { Perkmann, } \\
\text { M. }\end{array}$ & Imperial College London & UK & 12 & 562 & 7 \\
\hline 4 & Muscio, A. & University of Foggia & IT & 11 & 123 & 4 \\
\hline 5 & Salter, A. & Imperial College London & UK & 11 & 525 & 5 \\
\hline 6 & D'Este, P. & $\begin{array}{l}\text { Universitat Politècnica de } \\
\text { València }\end{array}$ & ES & 9 & 641 & 7 \\
\hline 7 & Brostrom, A. & Royal Institute of Technology & SE & 8 & 158 & 5 \\
\hline 8 & $\begin{array}{l}\text { Freitas, } \\
\text { I.M.B. }\end{array}$ & University of Turin & IT & 7 & 149 & 4 \\
\hline 9 & Geuna, A. & University of Turin & IT & 6 & 523 & 5 \\
\hline 10 & Park, H.W. & Yeungnam University & $\mathrm{KR}$ & 6 & 109 & 3 \\
\hline
\end{tabular}

Abbreviations: R, rank; H-UBC; H-index only with University Business Collaboration (UBC) and Technology Transfer; TC-UBC and TP-UBC, Total Citations (TC) and Total Production (TP) in UBC Indexed in Web of Science Essential Science Indicators, during the period from January 2016 to February 2018. NL, The Netherlands; UK, United Kingdom; IT, Italy; ES, Spain; SE, Sweden; KR, South Korea.

displays the results ranked according to the $\mathrm{H}$ index, total papers and citations.

The USA is the most productive country, with 190 papers. Half of this production corresponds to the last ten years (97 papers). The UK is the next country in the ranking, with 103. The third position is for Italy, with 63, papers followed by Spain, with 50 papers. The Netherlands appears in the fifth position after Germany and Japan.

\section{Discussion and Conclusions}

By adopting a bibliometric approach, this study contributes to the current literature by giving a global view of the academic research in technology transfer mechanisms through which UBC can be established. We argue that our study overcomes the limitations of previous studies that adopted a similar approach, by not only focusing on a specific country or territory, but also adopting an international perspective. The period of analysis considers publications from 1980 up to 2016 due the fact that in 1980 the Congress of USA enacted the Bayh-Dole Act, which eased the commercialization of university research and thus university-business collaboration as well $[38,50,64]$. The results show that the USA, England, Italy Spain and the Netherlands are the leading countries in this area, and all of them have shown a significant increase in their production over the last 10 years. The analysis also reveals that the major categories in which these publications fall have a strong focus on business, public administration and education.

The logic behind this lies in the fact that these areas are the ones more closely related to growth and economic development.

Regarding the study of the leading institutions, the countries hosting them are Spain, the USA, Belgium, and the UK.

Top institutions include the Consejo Superior de Investigaciones Científicas (Spain), followed by The Imperial College London (UK) and KU Leuven (Belgium). All these institutions have a similar $\mathrm{h}$ index, thus the productivity and impact factor are 
fairly comparable. Concerning the analysis of the most cited researchers, Perkmann, D'Este, Muscio, Salter and Leydesdorff (co-author of triple helix model) stand as important big names in this area, publishing their works in some of the highest standing journals in this field, such as Research Policy, Technovation and the Journal of Technology Transfer.

We believe this study can help not only academics but also practitioners to identify the leading authors, institutions, and most influential publications in this field. This research might be particularly useful for anyone interested in obtaining a global picture of the current literature on UBC, particularly PhD students or researchers that start investigating this topic. Although we have followed a rigorous methodology, the study is not free of limitations. The bibliometric approach of this study is only informative. The analysis is biased to the records displayed in only one database, the Web of Science.

\section{Acknowledgements}

This work has been partially funded by The National Council of Science and Technology of México, CONACYT.

\section{References}

1. Abeda, M. I., Adnan, S. K., Saima, I., \& Aslan, A. S. (2011). Designing of success criteria-based evaluation model for assessing the research collaboration between university and industry. International Journal of Business Research and Management, Vol. 2, No. 2, pp. 59-73.

2. Abramo, G., D’Angelo, C. A., Di Costa, F., \& Sollazzi, M. (2009). University-industry collaboration in Italy: a bibliometric examination. Technovation, Vol. 29, No. 6, pp 498-507. DOI: 10.1016/j.technovation.2008.11.003.

3. Agrawal, A. \& Henderson, R. (2002). Putting patents in context: Exploring knowledge transfer from MIT. Management science, Vol. 48, No. 1, pp. 44-60. DOI: 10.1287/mnsc.48.1.44.14279.

4. Albert-László Barabási (2002). Linked: The new science of network. Cambridge, MA. Perseus.

5. Ankrah, S. \& AL-Tabbaa, O. (2015). Universitiesindustry collaboration: A systematic review. Scandinavian Journal of Management, Vol. 31, No.
3, pp. 387-408. DOI: 10.1016/j.scaman.2015.02.003.

6. Baldini, N., Grimaldi, R., \& Sobrero, M. (2007). To patent or not to patent? A survey of Italian inventors on motivations, incentives and obstacles to university patenting. Scientometrics, Vol. 70, No. 2, pp. 333-354. DOI: 10.1007/s11192-007-0206-5.

7. Barringer, B. R. \& Harrison, J. S. (2000). Walking a tightrope: Creating value through interorganizational relationships. Journal of management, Vol. 26, No. 3, pp. 367-403. DOI: 10.1016/S0149-2063(00)00046-5.

8. Bekkers, R. \& Freitas, I. M. B. (2008). Analysing knowledge transfer channels between universities and industry: To what degree do sectors also matter?. Research policy, Vol. 37, No. 10, pp. 18371853. DOI: 10.1016/j.respol.2008.07.007.

9. Berman, E. P. (2008). Why did universities start patenting? Institution-building and the road to the Bayh-Dole Act. Social studies of science Vol. 38, No. 6, pp. 835-871. DOI: $10.1177 / 0306312708098605$.

10. Blackman, C. \& Seagal, N. (1991). Access to skills and knowledge: Managing the relationships with higher education institutions. Technology Analysis \& Strategic Management, Vol. 3, No. 3, pp. 297303.

11. Blanco-Mesa, F., Merigó, J. M., \& Gil-Lafuente, A. M. (2017). Fuzzy decision making: a bibliometricbased review. Journal of Intelligent \& Fuzzy Systems, Vol. 32, No. 3, pp. 2033-2050. DOI: 10.3233/JIFS-161640.

12. Bodas Freitas, I. M., Marques, R. A., \& Silva, E. M. P. (2008). University-industry collaboration and the development of high-technology sectors in Brazil. Georgia Institute of Technology.

13. Bonaccorsi, A. \& Piccaluga, A. (1994). A theoretical framework for the evaluation of university-industry relationships. $R \& D$ Management, Vol. 24, No. 3, pp. 229-247. DOI: 10.1111/j.1467-9310.1994.tb00876.x.

14. Bonilla, C., Merigó, J. M., \& Torres-Abad, C. (2015). Economics in Latin America: A bibliometric analysis. Scientometrics, Vol. 105, No. 2, pp. 12391252. DOI: $10.1007 / \mathrm{s} 11192-015-1747-7$.

15. Bramwell, A. \& Wolfe, D. A. (2008). Universities and regional economic development: the entrepreneurial University of Waterloo. Research Policy, Vol. 37, 8, pp 1175-1187. DOI: 10.1016/j.respol.2008.04.016.

16. Bruneel, J., D'Este, P., \& Salter, A. (2010). Investigating the factors that diminish the barriers to university-industry collaboration. Research Policy, 
Vol. 39, No. 7, pp. 858-868. DOI: 10.1016/j.respol.2010.03.006.

17. Caldera, A. \& Debande, O. (2010). Performance of Spanish universities in technology transfer: An empirical analysis. Research Policy, Vol. 39, No. 9, pp. 1160-1173. DOI: 10.1016/j.respol.2010.05.016.

18. Calvert, J. \& Patel, P. (2003). University-industry research collaborations in the UK: bibliometric trends, Science and Public Policy, Vol. 30, No. 2, pp. 85-96. DOI: 10.3152/147154303781780597.

19. Cancino, C., Merigó, J. M., Coronado, F., Dessouky, Y., \& Dessouky, M. (2017). Forty years of computers \& industrial engineering: A bibliometric analysis. Computers \& Industrial Engineering, Vol. 113, pp. 614-629. DOI: 10.1016/j.cie.2017.08.033.

20. Cobo, M. J., Lopez-Herrera, A. G., HerreraViedma, E., \& Herrera, F. (2011). Science mapping software tools: Review, analysis and cooperative study among tools. Journal of the American Society for Information Science and Technology, Vol. 62, No. 7, pp. 1382-1402. DOI: 10.1002/asi.21525.

21. Cohen, W. M. \& Levinthal, D. A. (1989). Innovation and learning: the two faces of R\&D. Economic Journal, Vol. 99, No. 397, pp. 569-596. DOI: $10.2307 / 2233763$.

22. D'Este, P. \& Patel, P. (2007). University-industry linkages in the UK: what are the factors underlying the variety of interactions with industry?. Research Policy, Vol. 36, No. 9, pp. 1295-1313. DOI: 10.1016/j.respol.2007.05.002.

23. Davey, T., Baaken, T., Galan-Muros, V., \& Meerman, A. (2011). Study on the cooperation between Higher Education Institutions and public and private organisations in Europe. European Commission, DG Education and Culture, Brussels pp. 978-992.

24. Debackere, K. \& Veugelers, R. (2005). The role of academic technology transfer organizations in improving industry science links. Research Policy, Vol. 34, No. 3, pp. 321-342. DOI: 10.1016/j.respol.2004.12.003.

25. Di Gregorio, D. \& Shane, S. (2003). Why do some universities generate more start-ups than others? Research Policy, Vol. 32, No. 2, pp. 209-227. DOI: 10.1016/S0048-7333(02)00097-5.

26. Dunowski, J. P., Schultz, C., Kock, A., Gemunden, H. G., \& Salomo, S. (2010). Implementing University Collaboration Strategies through Portfolio Management. Paper presented at the Summer Conference. Imperial College London Business School, pp.16-18.
27. Etzkowitz, H. \& Leydesdorff, L. (1998). The endless transition: A "triple helix" of universityindustry-government relations. Minerva, Vol. 36, No. 3, pp. 203-208.

28. Etzkowitz, H., Webster, A., Gebhardt, C., \& Terra, B. R. C. (2000). The future of the university and the university of the future: Evolution of ivory tower to entrepreneurial paradigm. Research Policy, Vol. 29, No. 2, pp. 313-330. DOI: 10.1016/S00487333(99)00069-4.

29. Garfield, E. (2006). The history and meaning of the journal impact factor. Jama, Vol. 295, No. 1, pp. 9093. DOI: 10.1001/jama.295.1.90.

30. Granowicz, G. (2012). Best of both worlds. Quality Progress, Vol. 44, No. 4, pp. 48-54.

31. Gulbrandsen, M. \& Smeby, J. C. (2005). Industry funding and university professors' research performance. Research Policy, Vol. 34, No. 6, pp. 932-950. DOI: 10.1016/j.respol.2005.05.004.

32. Haeussler, C. \& Colyvas, J. A. (2011). Breaking the ivory tower: academic entrepreneurship in the life sciences in UK and Germany. Research Policy, Vol. 40, No. 1, pp. 41-54. DOI: 10.1016/j.respol.2010.09.012.

33. Harris, R. G. (2001). The knowledge based economy: intellectual origins and new economic perspectives. International Journal of Management reviews, Vol. 3, No. 1, pp. 21-40. DOI: 10.1111/1468-2370.00052.

34. Hirsch, J. E. (2005). An index to quantify an individual's scientific research output. Proceedings of the National academy of Sciences, Vol. 102, No. 46, pp. 16569-16572. DOI: 10.1073/pnas.0507655102.

35. Hitt, M. A., Ireland, R. D., \& Lee, H. U. (2000). Technological learning, knowledge management, firm growth and performance: an introductory essay. Journal of Engineering and Technology management, Vol. 17, No. 3-4, pp. 231-246. DOI: 10.1016/S0923-4748(00)00024-2.

36. Jain, S., George, G., \& Maltarich, M. (2009). Academics or entrepreneurs? Investigating role identity modification of university scientists involved in commercialization activity. Research Policy, Vol. 38, No. 6, pp. 922-935. DOI: 10.1016/j.respol.2009.02.007.

37. Kaufmann, A. \& Tödtling, F. (2001). Scienceindustry interaction in the process of innovation: the importance of boundary-crossing between systems. Research Policy, Vol. 30, No. 5, pp. 791-804. DOI: 10.1016/S0048-7333(00)00118-9.

38. Kenney, M., Patton, D., (2009). Reconsidering the Bayh-Dole Act and the current university invention 
ownership model. Research Policy, Vol. 38, No. 9, pp. 1407-1422. DOI: 10.1016/j.respol.2009.07.007.

39. Kessler, M. M. (1963). Bibliographic coupling between scientific papers. American Documentation, Vol. 14, No. 1, pp. 10-25. DOI: 10.1002/asi.5090140103.

40. Klein, D. B. \& Chiang, E. (2004). The Social Science Citation Index: A Black Box--With an Ideological Bias?. Econ Journal Watch, Vol. 1, No. 1, pp. 134-165.

41. Laengle, S., Merigó, J. M., Miranda, J., Słowiński, R., Bomze, I., Borgonovo, E., Dyson, R. G., Oliveira, J. F., \& Teunter, R. (2017). Forty years of the European Journal of Operational Research: A bibliometric overview. European Journal of Operational Research, Vol. 262, No. 3, pp. 803816. DOI: 10.1016/j.ejor.2017.04.027.

42. Link, A., Siegel, D., \& Bozeman, B., (2007). An empirical analysis of the propensity of academics to engage in informal university technology transfer. Industrial and Corporate Change, Vol. 16, No. 4, pp. 641-655. DOI: 10.1093/icc/dtm020.

43. Link, A., Siegel, N., \& Donald, S., (2005). University-based technology initiatives: quantitative and qualitative evidence. Research Policy, Vol. 34, No. 3, pp. 253-257. DOI: 10.1016/j.respol.2005.01.005.

44. Lockett, A. \& Wright, M. (2005). Resources, capabilities, risk capital and the creation of university spin-out companies. Research Policy, Vol. 34, No. 7, pp. 1043-1057. DOI: 10.1016/j.respol.2005.05.006.

45. Macho-Stadler, I., Perez-Castrillo, D., \& Veugelers, R. (2007). Licensing of university innovations: The role of a technology transfer office. International Journal of Industrial Organization, Vol. 25, No. 3, pp. 483-510. DOI: 10.1016/j.jindorg.2006.06.001.

46. Martínez-López, F. J., Merigó, J. M., Valenzuela, L., \& Nicolás, C. (2018). Fifty years of the European Journal of Marketing: A bibliometric analysis. European Journal of Marketing, Vol. 52, No. 1/2, pp. 439-468.

47. Merigó, J. M., Cancino, C. A., Coronado, F., \& Urbano, D. (2016). Academic research in innovation: a country analysis. Scientometrics, Vol. 108, No. 2, pp. 559-593. DOI: 10.1007/s11192016-1984-4.

48. Merigó, J. M., Mas-Tur, A., Roig-Tierno, N., \& Ribeiro-Soriano, D. (2015b). A bibliometric overview of the Journal of Business Research between 1973 and 2014. Journal of Business Research, Vol. 68, No. 12, pp. 2645-2653. DOI: 10.1016/j.jbusres.2015.04.006.
49. Merigó, J. M., Pedrycz, W., Weber, R., \& de la Sotta, C. (2018). Fifty years of Information Sciences: A bibliometric overview. Information Sciences, Vol. 432, pp. 245-268. DOI: 10.1016/j.ins.2017.11.054.

50. Mowery, D. C., Nelson, R. R., Sampat, B. N., \& Ziedonis, A. A., (2004). Ivory tower and industrial innovation: University-industry technology before and after the Bayh-Dole Act in the United States. Stanford University Press, Stanford.

51. O’Shea, R. P., Allen, T. J., Chevalier, A., \& Roche, F. (2005). Entrepreneurial orientation, technology transfer and spinoff performance of US universities. Research Policy, Vol. 34, No. 7, pp. 994-1009.DOI: 10.1016/j.respol.2005.05.011.

52. Owen-Smith, J. \& Powell, W. W. (2001). To patent or not: faculty decisions and institutional success at technology transfer. Journal of Technology Transfer, Vol. 26, No. 1/2, pp. 99-114. DOI: 10.1023/A:1007892413701.

53. Podsakoff, P. M., MacKenzie, S. B., Podsakoff, N. P., \& Bachrach, D. G. (2008). Scholarly influence in the field of management: A bibliometric analysis of university and author impact on the management literature during the past quarter century. Journal of Management, Vol. 34, No. 4, pp. 641-720. DOI: 10.1177/0149206308319533.

54. Porter, M. E. \& Van Opstal, D. (2001). US competitiveness 2001: Strengths, vulnerabilities and long-term priorities. Washington, D.C.: Council on Competitiveness.

55. Rohrbeck, R. \& Arnold, H. M. (2006). Making university-industry collaboration work-a case study on the Deutsche Telekom Laboratories contrasted with findings in literature. ISPIM Annual Conference: "Networks for Innovation". Athens, Greece pg.11. DOI: 10.2139/ssrn.1476398.

56. Santoro, M. D. \& Gopalakrishnan, S. (2000). The institutionalization of knowledge transfer activities within industry-university collaborative ventures. Journal of Engineering and Technology Management, Vol. 17, No. 3-4, pp. 299-319. DOI: 10.1016/S0923-4748(00)00027-8.

57. Santoro, M. D. \& Chakrabarti, A. K. (2002). Firm size and technology centrality in industry-university interactions. Research Policy, Vol. 31, No. 7, pp. 1163-1180. DOI: 10.1016/S0048-7333(01)001901.

58. Schartinger, D., Rammer, C., Fischer, M., \& Froehlich, J. (2002). Knowledge interactions between universities and industry in Austria: Sectoral patterns and determinants. Research Policy, Vol. 31, No. 3, pp. 303-328. 
59. Siegel, D. S. (2003). Data requirements for assessing the private and social returns to strategic research partnerships: Analysis and recommendations. Technology Analysis \& Strategic Management, Vol. 15, No. 2, pp. 207-225.

60. Siegel, D. S., Veugelers, R., \& Wright, M. (2007). Technology transfer offices and commercialization of university intellectual property: performance and policy implications. Oxford Review of Economic Policy, Vol. 23, No. 4, pp. 640-660. DOI: 10.1093/oxrep/grm036.

61. Siegel, D. S., Waldman, D., \& Link, A. (2003). Assessing the impact of organizational practices on the relative productivity of university technology transfer offices: an exploratory study. Research Policy, Vol. 32, No. 1, pp. 27-48. DOI: 10.1016/S0048-7333(01)00196-2.

62. Sine, W. D., Shane, S., \& Gregorio, D. D. (2003). The halo effect and technology licensing: the influence of institutional prestige on the licensing of university inventions. Management Science, Vol. 49, No. 4, pp. 478-496. DOI: 10.1287/mnsc.49.4.478.14416.

63. Small, H. (1973). Co-citation in the scientific literature: A new measure of the relationship between two documents. Journal of the American Society for Information Science, Vol. 24, No. 4, pp. 265-269. DOI: 10.1002/asi.4630240406.
64. So, A. D., Sampat, B. N., Rai, A. K., CookDeegan, R., Reichman, J. H., Weissman, R., \& Kapczynski, A., (2008). Is Bayh-Dole good for developing countries? Lessons from the US experience. PLoS Biology, Vol. 6, No. 10, DOI: 10.1371/journal.pbio.0060262.

65. Van Eck, N. J. \& Waltman, L. (2010). Software survey: VOSviewer, a computer program for bibliometric mapping. Scientometrics, Vol. 84, No. 2, pp. 523-538.

66. Welsh, R., Glenna, L., Lacy, W., \& Biscotti, D. (2008). Close enough but not too far: assessing the effects of university-industry research relationships and the rise of academic capitalism. Research Policy, Vol. 37, No. 10, pp. 1854-1864. DOI: 10.1016/j.respol.2008.07.010.

67. Yu, D., \& Shi, S. (2015). Researching the development of Atanassov intuitionistic fuzzy set: Using a citation network analysis. Applied Soft Computing, Vol. 32, pp. 189-198. DOI: 10.1016/j.asoc.2015.03.027.

68. Yusuf, S. (2008). Intermediating knowledge exchange between universities and businesses. Research Policy, Vol. 37, No. 8, pp. 1167-1174. DOI: 10.1016/j.respol.2008.04.011.

Article received on 10/05/2018; accepted on 15/07/2018. Corresponding author is Claudia Olvera. 